Original Article

\title{
EFFICACY OF WATTAKAKA VOLUBILIS AGAINST ALUMINIUM SULPHATE INDUCED IN LIVER TOXICITY
}

\author{
USHARANI . $^{* 1}$, ANURADHA R. ${ }^{1}$ \\ ${ }^{1}$ PG and Research Department of Biochemistry, Sengamala Thayaar Educational Trust, Mannargudi 614001 Tamil Nadu, India \\ Email: usharani1886@gmail.com
}

Received: 03 Nov 2017 Revised and Accepted: 03 Jan 2018

\begin{abstract}
Objective: The modulation of membrane-bound ATPases, carbohydrate metabolizing enzymes and mitochondrial TCA cycle enzymes in Wattakaka volubilis on aluminium sulphate induced liver toxicity.

Methods: Medicinal therapy requires careful assessment of effective treatment offering an acceptable safety over human health. Experimental animals were divided into five groups (Untreated, negative and positive control, hepatic group and the hepatic group fed on Wattakaka volubilis), Metabolising enzymes level, estimation of DNA, RNA and quantification of DNA fragmentation and gene expression were investigated. These altered enzyme levels were ameliorated significantly by administration of Wattakaka volubilis at the concentration of $200 \mathrm{mg} / \mathrm{kg}$ in drug-treated animals.

Results: Results showed that treatment with methanol extract of Wattakaka volubilis normal level of enzymes which are compared with silymarin. This was evident from the significant increase in $\mathrm{p}<0.05, \mathrm{p}<0.01, \mathrm{p}<0.001$ enzyme levels. Aluminium sulphate induced rats showed decreased the activities of metabolising enzymes and increased DNA fragmentation in the liver. This clearly explained the reason for the hepatoprotective activity of Wattakaka volubilis leaf extract.
\end{abstract}

Conclusion: The methanolic leaf extract of $W$. volubilis showed high protective activity against aluminium sulphate.induced hepatotoxicity.

Keywords: Metabolising enzymes, DNA, RNA, DNA fragmentation, $W$. Volubilis

(C) 2018 The Authors. Published by Innovare Academic Sciences Pvt Ltd. This is an open-access article under the CC BY license (http://creativecommons.org/licenses/by/4.0/) DOI: http://dx.doi.org/10.22159/ijpps.2018v10i2.23461

\section{INTRODUCTION}

The liver plays a central and crucial role in the regulation of carbohydrate metabolism. Its normal functioning is essential for the maintenance of blood glucose levels and continued supply to organs that require a glucose energy source [1]. In addition, it has a great capacity to detoxify toxic substances and synthesize useful ones. Therefore, the damage which is caused by hepatotoxic agents is of grave consequence to the body as it deprives the liver of its principal functions [2]. A significant amount of liver damage is induced by lipid peroxidation and other oxidative damages which are caused by the hepatotoxic chemicals $[3,4]$. It has been reported that liver injury caused by a variety of deleterious agents induces inflammation, necrosis, fibrosis cirrhosis and functional deteriorations [5]. Liver is a vital organ, responsible for the detoxification of various drugs and xenobiotics in the body. The drug-induced liver disease accounts for $5 \%$ of all hospital admissions and $50 \%$ of all acute liver failure [6]. It is the major cause of withdrawal of an approved drug from the market [7]. Currently, $25 \%$ of all modern medicines are directly or indirectly derived from higher plants. Aluminium is a ubiquitous element comprising about $8 \%$ of the earth's crust. It is a non-essential metal to which humans are frequently exposed. Food ingredients, antacids, buffered vaccines, allergen, injections, food preparations all contain a considerable amount of aluminium. A small amount of aluminium $(<1 \%)$ is systematically absorbed and is excreted principally in the urine and to a lesser extent in the faces. Aluminium (Al) has been reported to be neurotoxic when injected directly into the brain. Evidence for the contribution of aluminium to environmental pollution with the different aluminium containing compounds exposes people to higher than normal levels of aluminium. $\mathrm{Al}$ is thus potentially toxic for humans. Agency for Toxic Substances and Disease Registry (ATSDR) reported that aluminium is distributed mainly in bone, liver, testis, kidneys and brain [8]. Patients on dialysis or on long-term treatment with total parenteral nutrition [9, 10] have been shown to accumulate this metal in different organs. The human toxicological effects include encephalopathy, bone disease, anemia and skeletal system disease [11-13]. Aluminum has been intensively investigated in the initiation and progression of various neurological disorders which is caused due to oxidative stress. Different forms of aluminium are environmental xenobiotics that induce free radical-mediated cytotoxicity and reproductive toxicity. Aluminium ( $\mathrm{Al}$ ) causes oxidative stress within brain tissue. $\mathrm{Al}$ has a direct effect on haematopoisis. Excess aluminium has been shown to induce microcytic anaemia [14].

The leaves are applied to boils and abscesses to promote suppuration [15]. W. volubilis (Asclepiadaceae) is distributed throughout the hotter parts of India, Taiwan, Cambodia, Nepal and Sri Lanka [16]. The chief phytoconstituents reported in the leaves and stems of $W$. volubilis are glycosides, flavonoids, triterpenoids and saponins [17]. W. volubilis leaf extract is reported to possess anti-inflammatory and analgesic activities [18]. The plant is also reported to possess mild central nervous system depressant, anthelmintic, antispasmodic, cytotoxic, antimutagenic and anticancer properties [19]. The roots of $W$. volubilis are reported to possess antipyretic activity [20]. Recent studies have shown that phytochemical constituents like flavonoids and triterpenoids are known to promote the wound healing process mainly due to their astringent and antimicrobial properties. This study was undertaken to substantiate the traditional use of the leaves of $W$. volubilis for the treatment of membrane ATPases, carbohydrate metabolizing and mitochondrial TCA cycle enzymes.

\section{MATERIALS AND METHODS}

\section{Plant material}

The leaves of $W$. volubilis were collected from Trichy, Tamil Nadu, India. The plant material was taxonomically identified voucher specimen (voucher specimen No. 001) by Dr. John Britto Rabinet Herbarium. St. Joseph's College, Trichy.

\section{Drugs and chemicals}

Aluminium sulphate and silymarin were purchased from the sigmaaldrich chemical company (St. Lousis mo, USA). The diagnostic kits 
required for enzymatic assays were purchased from Span Diagnostics, India.

\section{Preparation of extract}

The leaves of $W$. volubilis were dried in shady condition and powdered. The $200 \mathrm{~g}$ of powdered material was dissolved with 250 $\mathrm{ml}$ of $95 \%$ methanol and the extract was prepared using soxhlet apparatus for $48 \mathrm{hr}$. The extract was filtered and concentrated in the rotatory evaporator at $35-40{ }^{\circ} \mathrm{C}$ under reduced pressure and was stored in refrigerated condition for further use.

\section{Experimental animals}

Adult male Wister Albino rats weighing 250-350 g were used for the present investigation. They were housed in a clean polypropylene cage and maintained under standard laboratory conditions (temperature $26 \pm 2{ }^{\circ} \mathrm{C}$ with dark/light cycle $12 / 12 \mathrm{~h}$ ). They were fed with standard pellet diet (Hindustan lever, Kolkata, India) and water ad libitum. The animals were acclimatized to laboratory conditions for one month. All procedures described were reviewed and approved by the animal ethics committee, IAEC No/232 Sastra University, Thanjavur, Tamil Nadu, India.

\section{Experimental design}

The animals were divided into 5 groups consisting of 6 animals in each group.

Group I-Untreated rats received with saline $(1 \mathrm{ml} / \mathrm{kg})$.

Group II-Diseased control aluminium sulphate $(50 \mathrm{mg} / \mathrm{kg} /$ day $)$ dissolved in $(1 \mathrm{ml} / \mathrm{kg})$ saline will be injected intraperitoneally double dose per week to induce hepatotoxicity. (Domingo J. L. 1995).

Group III-Aluminium sulphate+treated with methanol extract of Wattakaka volubilis (MEWV) $(200 \mathrm{mg} / \mathrm{kg})$ dissolved in corn oil (1 $\mathrm{ml} / \mathrm{kg}$ ) orally for $30 \mathrm{~d}$.

Group IV-Aluminium sulphate+treated with silymarin $(25 \mathrm{mg} / \mathrm{kg})$ dissolved in corn oil ( $1 \mathrm{ml} / \mathrm{kg}$ ) orally for $30 \mathrm{~d}$.

Group V-Treated with Methanol extract of Wattakaka volubilis (MEWV) alone $(200 \mathrm{mg} / \mathrm{kg})$ dissolved in corn oil $(\mathrm{ml} / \mathrm{kg})$ orally for $30 \mathrm{~d}^{*}$.

The body weights of rats of each group were measured before the experimental trial and $30 \mathrm{~d}^{*}$ after the methanol extract of Wattakaka volubilis treatment. Liver weight of all rats was measured after the sacrifice. Animals were sacrificed by injecting with sodium pentobarbitone and blood was collected in plain and heparinised tubes immediately after sacrifice for biochemical assays. The liver was removed and washed with saline. Blood samples centrifuged for $10 \mathrm{~min}$ at $2500 \mathrm{rpm}$ and the serum separated stored at $4{ }^{\circ} \mathrm{C}$ until further use.

\section{Biochemical analysis}

Deoxyribonucleic acid (DNA) was estimated by the method of Burton [21]. Ribonucleic acid (RNA) was estimated by the method of Rawal et al., [22]. $\mathrm{Na}^{+} \mathrm{K}^{+}$-ATPase was estimated by the method of Bonting [23], The activity of Ca2+-ATPase was assayed according to the method of Hjerten and Pan [24], Mg2+ATPase activity was assayed by the method of Ohinishi et al., [25]. Hexokinase was assayed by the method of Brandstrup et al., [26] Aldolase and Glucose-6-phosphatease was estimated by the method of King [27] Estimation of Isocitrate dehydrogenase (ICDH) by the method of King [27], Succinate dehydrogenase (SDH) was estimated by the method of Slater and Borner [28]. Malate dehydrogenase (MDH) assayed by the method of Mehler et al., [29]. Alpha-ketoglutarate dehydrogenase $\alpha-(\mathrm{KGDH})$ by the method of Reed and Mukherjee [30].

\section{Statistical analysis}

The data were statistically analysed and all the values were expressed as mean \pm Standard Error Mean (SEM). The data were also analyzed by one way ANOVA followed by Dunnet's t3-test. $p<0.05$, $p<0.01, p<0.001$ was considered significant.

\section{RESULTS}

The membrane-bound enzymes such as $\mathrm{Na}^{+}, \mathrm{Ca}^{2+}, \mathrm{Mg}{ }^{2+}$ and total ATPases, in erythrocyte membrane and liver of aluminium sulphate induced group II animals showed a significant decline in the levels of $\mathrm{Na}^{+}, \mathrm{Ca}{ }^{2+}, \mathrm{Mg}^{2+}$ and total ATPases $(\mathrm{p}<0.05)$ when compared to control animals. These levels were found to be significantly increased where treated with a methanolic extract of $W$. volubilis $(\mathrm{p}<0.05)$ in group III animals when compared to group II animals. On the other hand, there were no significant variations in group IV drug alone and silymarin treated animals when compared to group I control animals (fig. 1).

The effect of $W$. volubilis on the mitochondrial TCA cycle enzymes such as ICDH, SDH, MDH, NADPH and $\alpha$-KGDH in the hepatoprotective potential activity of control and experimental animals are given in fig. 2. A significant decrease in the levels of TCA cycle enzymes was observed in group II animals when compared to group I control animals $(p<0.05)$. In this connection, the levels of TCA cycle enzymes are significantly increased in group III animals treated with a methanolic extract of $W$. volubilis $(\mathrm{p}<0.05)$ when compared to group II aluminium sulphate induced animals. No significant changes in group IV and group V administered animals when compared with group I control animals were observed.

The efficacy of $W$. volubilis on the levels of carbohydrate metabolizing enzymes in liver of control and experimental animals are presented in fig. 3 . In the hepatoprotective activity of the carbohydrate metabolizing enzymes such as hexokinase and aldolase were significantly elevated $(\mathrm{p}<0.05)$ and the glucose- 6 phosphatase and Glucose 6-phosphatase dehydrogenase were significantly decreased $(\mathrm{p}<0.05)$ in group II animals when compared to group I control animals. All the carbohydrate metabolizing enzymes were significantly altered when treated with $W$. volubilis in group III animals $(\mathrm{p}<0.05)$ when compared to group II aluminium sulphate induced animals. No remarkable changes were observed in group IV drug alone and silymarin treated animals when compared to group I animals.

The results of the present study indicated that the level of DNA in the liver of aluminium sulphate treated rats showed a significant decrease when compared to that of normal control. However, there was a significant increase in the level of DNA in the liver of aluminium sulphate treated rats along with plant extracts and standard drug. Thus, the results revealed recovery in the level of DNA content in the liver of rat exposed to aluminium sulphate along with plant extracts when compared to that of aluminium sulphate treated control group (fig. 4). In the present study, the level of RNA in the liver of aluminium sulphate treated group showed a significant decrease when compared with that of normal control. However, a significant increase in the RNA content was observed in the liver of aluminium sulphate treated rats along with plant extracts when compared to that of group II treated group. Thus, the results indicated a recovery in the level of RNA in rat exposed to aluminium sulphate along with plant extracts and drug alone, standard drug when compared with that of aluminium sulphate treated control group.

The fig. 5 shows the agarose gel electrophoretic pattern of DNA fragmentation in control and experimental rats. DNA ladder (100$1000 \mathrm{bp}$ ) is shown in lane 1 . It was found that there was a marked increase in the levels of DNA fragmentation in aluminium sulphate induced rats (lane 6) when compared to aluminium+silymarin (lane 2). On treatment with MEWV which restores the aluminium sulphate induced DNA fragmentation to near control (lane 3). The fig. 6 shows the Polymerase Chain Reaction (PCR) results for MMP-2 gene. The results were showed from the 100-300 bp the maximum action was shown in the 129bp. This indicates that MMP2 gene was involved in the gene expression. 


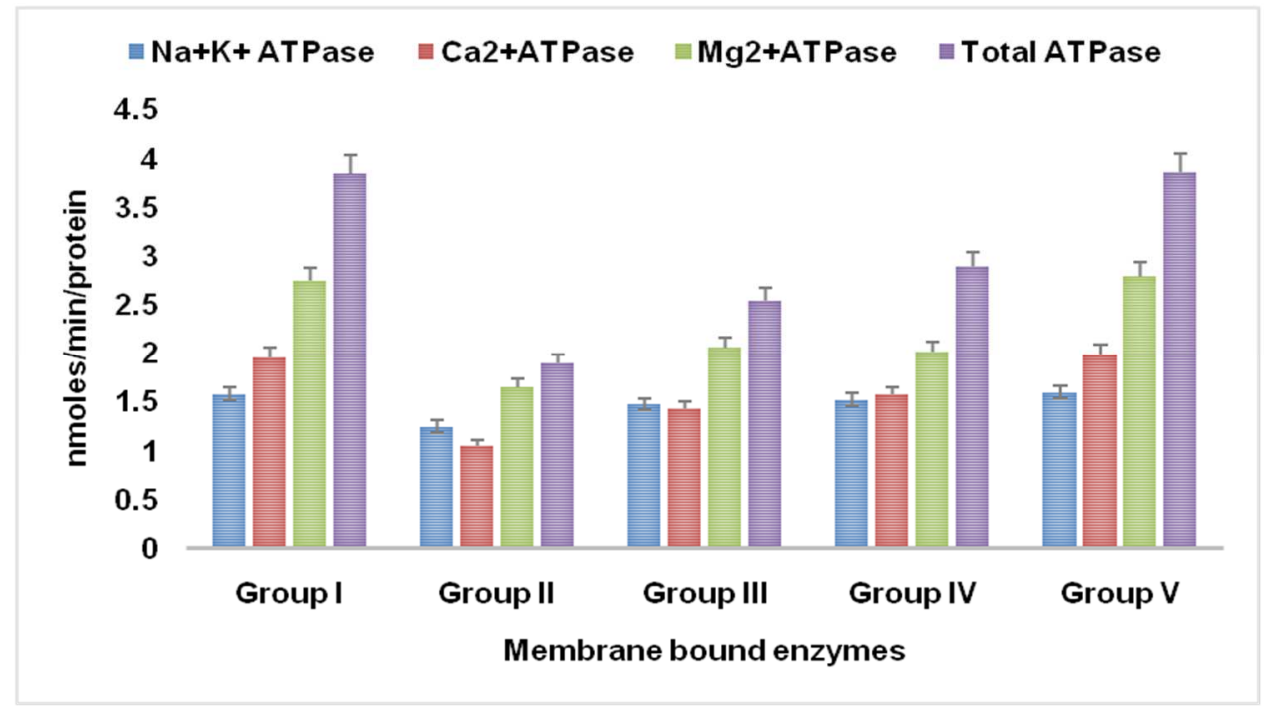

Fig. 1: Effect on MEWV of membrane bound enzymes in control and experimental rats, Results are expressed as mean $\pm S E M, n=6 . * P<0.05$, statistically significant as compared with control rats and $\mathrm{a}<0.05$ statistically significant as compared with $\mathrm{Al}_{2}\left(\mathrm{SO}_{4}\right)_{3}$ induced group

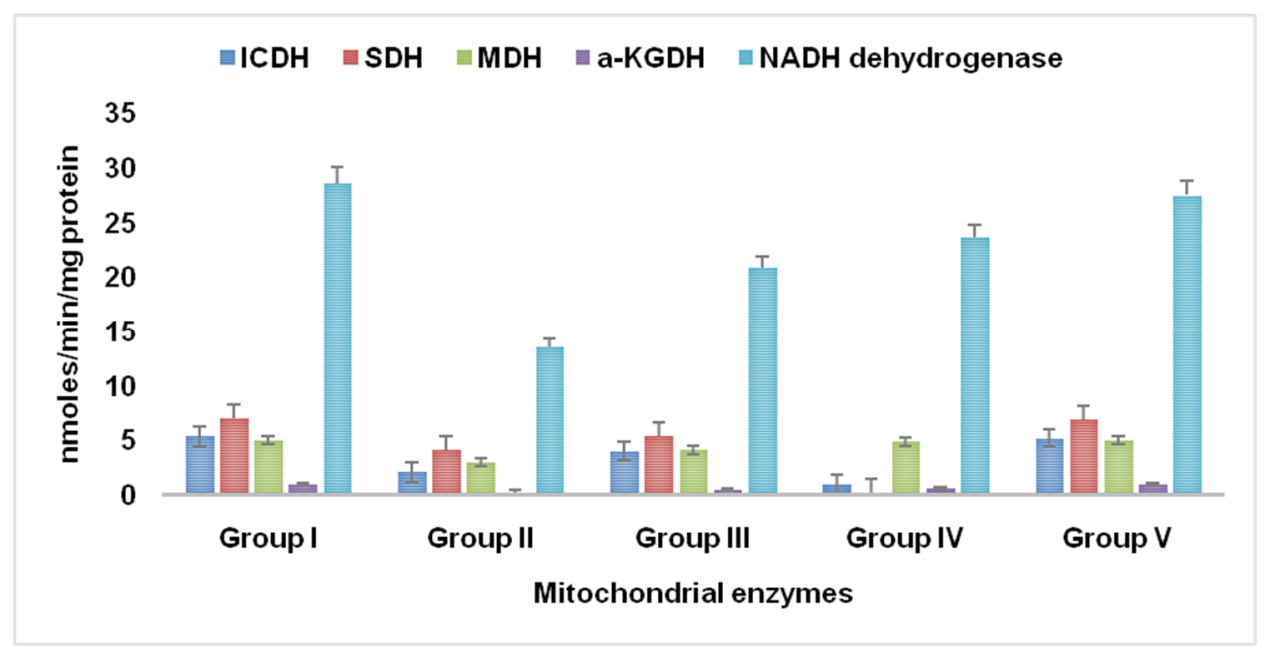

Fig. 2: Effect on MEWV of mitochondrial enzymes in control and experimental rats, results are expressed as mean $\pm S E M, n=6 .{ }^{*} P<0.05$, statistically significant as compared with control rats and $\mathrm{P}<0.05$ statistically significant as compared with $\mathrm{Al}_{2}\left(\mathrm{SO}_{4}\right)_{3}$ induced group

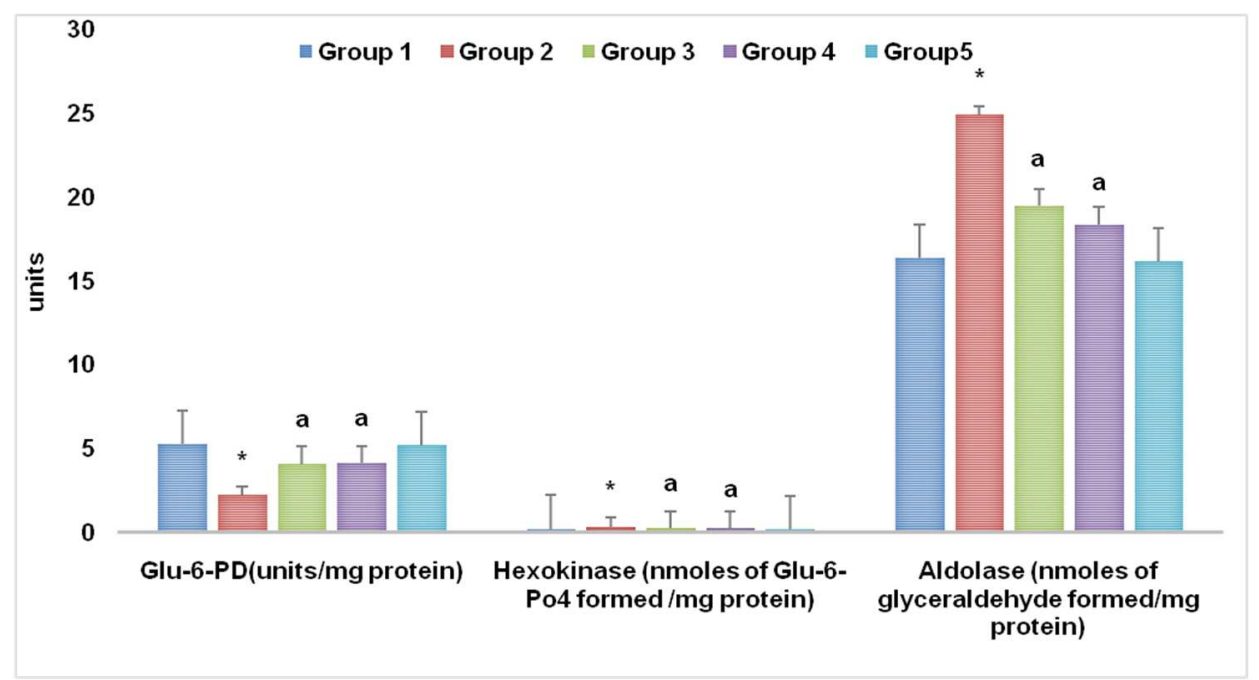

Fig. 3: Effect of glucose metabolizing enzymes in control and experimental rats, results are expressed as mean $\pm S E M, n=6$. ${ }^{*} P<0.001$, statistically significant as compared with control rats and a $\mathrm{P}<0.001$ statistically significant as compared with $\mathrm{Al}_{2}\left(\mathrm{SO}_{4}\right)_{3}$ induced group 


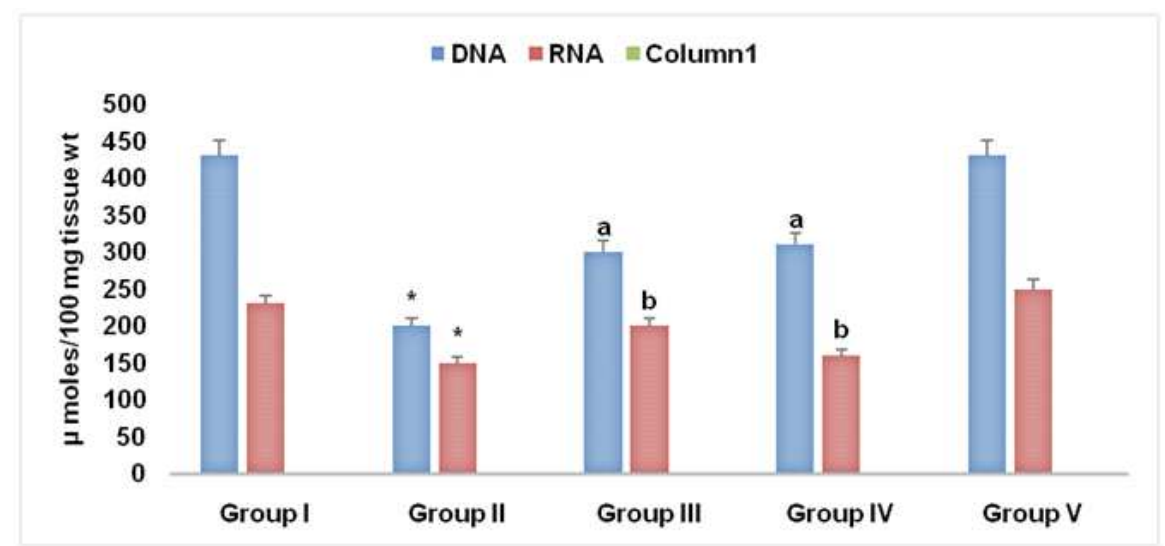

Fig. 4: Effect on MEWV of DNA and RNA content in control and experimental groups, results are expressed as mean $\pm S E M, n=6$. ${ }^{*}<0.001$, statistically significant as compared with control rats and ${ }^{\mathrm{P}}<0.01$ and ${ }^{\mathrm{b}} \mathrm{P}<0.05$ statistically significant as compared with $\mathrm{Al}_{2}\left(\mathrm{SO}_{4}\right)^{3}$ control group

$\begin{array}{lllllll}1 & 2 & 3 & 4 & 5 & 6 & 7\end{array}$

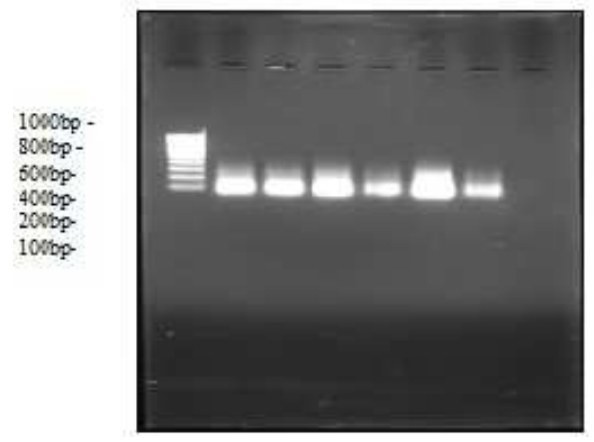

Fig. 5: Effect of MEWV on agarose gel electrophoretic pattern of hepatic DNA-Fragmentation in control and experimental rats, Lane 1: 1 kb DNA ladder; Lane 2: aluminium sulphate+silymarin treated group

Lane 3: aluminium sulphate+MEWV $(200 \mathrm{mg} / \mathrm{kg})$ showed very less DNA smearing when compared with group II Lane 4: aluminium sulphate+MEWV $(100 \mathrm{mg} / \mathrm{kg})$ showed moderate DNA smearing when compared with group II Lane 5: MEWV $(200 \mathrm{mg} / \mathrm{kg})$ alone treated group Lane 6: aluminium Sulphate induced group liver tissue DNA was highly damaged indicated by more smearing of DNA. Lane 7: Normal control.

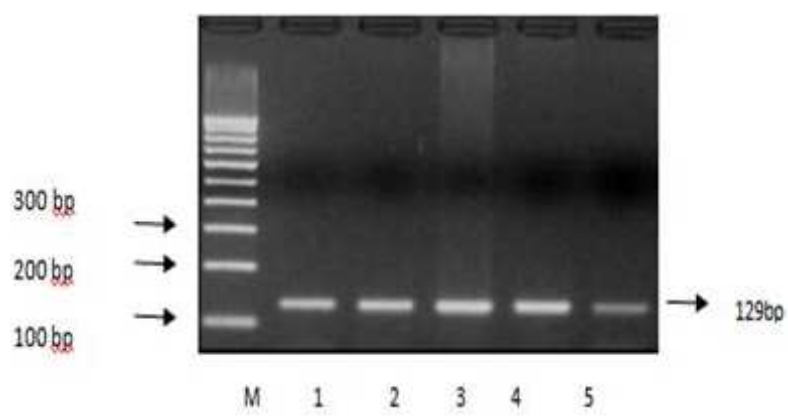

Fig. 6: Effect of MEWV on PCR-MMP-2 gene in aluminium sulphate induced rats, Lane M: Marker; Lane 1: MEWV (200 $\mathrm{mg} / \mathrm{kg}$ ) alone treated group; Lane 2: aluminium sulphate+silymarin treated group; Lane 3 : aluminium sulphate+methanol extract of Wattakaka volubilis (MEWV) (200 $\mathrm{mg} / \mathrm{kg}$ ); Lane 4: aluminium sulphate induced group; Lane 5: Normal control

\section{DISCUSSION}

Adenosine triphosphatases (ATPases) are a vital enzyme for providing metabolic energy to the living process. It regulates ion transport across the cellular membrane, cellular volume, osmotic pressure and membrane permeability. It is an integral part of the membrane structure [31]. The membrane-bound enzymes such as $\mathrm{Na}+/ \mathrm{K}^{+}, \mathrm{Ca}^{2+}$ and $\mathrm{Mg}{ }^{2+} \mathrm{ATPases}$ are responsible for the transport of sodium, potassium and calcium ions across the membrane. These lipids dependent enzymes have been implicated in the pathogenesis of liver injury [32]. In the present study, the level of $\mathrm{Na}+/ \mathrm{K}^{+}, \mathrm{Ca}^{2+}$ and $\mathrm{Mg}^{2+}$ ATPases was found to decrease in erythrocyte membrane and liver of aluminium sulphate induced hepatic animals. The calcium pump Ca2+ATPases in plasma membrane because of its high affinity has been proposed as the structure responsible for the maintenance of cytoplasmic calcium concentration at even sub micromolar level [33]. In the present investigation, it was observed that the level of $\mathrm{Ca} 2+\mathrm{ATPases}$ was inhibited in erythrocyte membrane and liver in $\mathrm{Al}_{2}(\mathrm{SO} 4)_{3}$ administered animals. It is well known that magnesium has a vital role in the maintenance of structure, metabolism and energetics of the cell. The synthesis of protein, nucleic acids and a number of other mitochondrial processes require magnesium. According to Frank et al., [34] changes in the cytosolic $\mathrm{Mg} 2+$ concentration lead to a significant modification in cellular functions. Decreased levels of $\mathrm{Mg}^{2+}$ were observed in this present investigation may be attributed to increased lipid peroxidation (LPO) and membrane damaged by aluminium sulphate. However, $W$. volubilis drug-treated rats showed near normal levels.

Mitochondria, the energy reservoir of the cell is vital for producing energy for the sustenance of the cell. Aluminium damage to mitochondria leads to cell death [35]. The inner and outer membranes of mitochondria contain unsaturated lipids and they are susceptible to free radicals attack [36]. The mitochondrial dysfunction during aluminium sulphate toxicity resulted from the declined activities of TCA enzymes and respiratory chain complexes, which are ascribed to the ROS generated by $\mathrm{ccl}_{4}$ [37]. In this study, the activities of the major TCA enzymes such as ICDH, $\alpha$-KGDH, SDH and MDH were declined significantly in the aluminium sulphate control compared with that of normal rats. The reduction in activities of TCA enzymes may be due to the structural and functional disorganization of the mitochondrial assembly and induced by the generated ROS. Thus, when mitochondrial are damaged, energy generation in them is inevitably inhibited which contributes to the overall loss in the energy production [38].

Glucose-6-phospatase is located in the endoplasmic reticulum and in the crucial enzyme of glucose homeostasis. It plays an important role in the regulation of the blood glucose level [39] reported various toxicants caused a significant decline in glucose-6-phospatase activity. The activity of this enzyme was significantly decreased after aluminium exposure, which indicates that glycogen is not converted 
into glucose as this enzyme is inactivated by combining with metal ions [40]. It reflects that $W$. volubilis can protect the structural integrity and probably shield against the deleterious effect of lipid peroxidation. It is well known that hepatic damage not only inflicts structural changes but also result in the altered functionality of the liver, particularly the carbohydrate metabolism [41]. The present study showed an increase in the glycolytic enzymes such as hexokinase, aldolase and a significant decrease in glucose-6phosphatase in aluminium sulphate treated animals. One of the strategies to prevent disease is the use of specific nutrients to protect tissues against toxic, carcinogenic injury and degenerative diseases [42, 43]. On methanol extract of $W$. volubilis treatment, the level of the enzyme was reverted back to near normal levels due to the activity of maintenance of glucose homeostasis.

Nucleic acids like RNA and DNA are most important macromolecules that carry all kinds of necessary biological information and are involved in gene action, which is essential in the regulation of cell metabolism and expression of the characters synthesized in the nucleus but mainly found in the cytoplasm to carry out the protein synthesis. The biochemical content of DNA and RNA were estimated and found significantly decreased in aluminium sulphate $\left(\mathrm{Al}_{2}\left(\mathrm{SO}_{4}\right)_{3}\right)$ treated group and increased in extract treated group which was almost equivalent to that of the normal group in the present study. Previously Phyllanthus amarus extract increased DNA and RNA contents in the liver tissue [44]. In the present study, $200 \mathrm{mg} / \mathrm{kg}$ showed the better result when restoring normal activity of enzymes and biochemical contents. Similar results of effective mitigation of toxic effects of carbon tetrachloride in a dose-dependent manner and thus offered significant protection was also reported [45].

A previous study we found that that there was a marked increase in the levels of DNA fragmentation in high cholesterol diet (HCD) induced rats when compared to control rats due to increased ROS production which alters the macromolecules such as lipid, protein and especially nucleic acid-DNA [46]. The present study lane 3 of agarose gel smear (aluminium sulphate+Wattakaka volubilis) (200 $\mathrm{mg} / \mathrm{kg}$ ) showed very less DNA smearing when compared to group II animals. This shows that some sort of DNA structural modifications was undergone in the smear. The lane 4 exhibits (aluminium Sulphate+mehanolic extract of wattakaka volubilis $(100 \mathrm{mg} / \mathrm{kg})$ showed moderate DNA smearing when compared with group II animals. The lane 6 smear possess (aluminium Sulphate induced group) liver tissue DNA was highly damaged indicated by more smearing of DNA. From this study, it comes to know that DNA damage occurs after ingestion of aluminium sulphate $\mathrm{AI}_{2}\left(\mathrm{SO}_{4}\right)_{3}$ and our methanol extract of $W$. volubilis (MEWV) of $200 \mathrm{mg}$ restore the DNA damage into its normal level.

Many pathological processes involve breakdown and remodelling of the extracellular matrix, which is mediated by the matrix metalloproteinases (MMP). MMP-2 and MMP-9 over-expression has been reported in cardiac [47] lung [48] and brain ischemiareperfusion injury [49]. The lane 2 which consists of (aluminium Sulphate+silymarin treated group). the lane 3 which exhibits aluminium sulphate+methanol extract of Wattakaka volubilis (MEWV) $(200 \mathrm{mg} / \mathrm{kg})$, whereas lane 4 includes aluminium sulphate induced group from this study, it comes to know that, expression of matrix metalloproteinases-2 (MMP-2) was a detected in all experimental groups and a high level of increase was noticed in aluminium sulphate induced group. A mild expression of MMP-2 observed in all other groups when compared with the aluminium sulphate induced group.

\section{CONCLUSION}

The results of the present study provide a scope for an in-depth and comprehensive study that can lead to the formulation of new therapeutic intervention for the treatment of liver toxicity as a valuable substitute to the present hepatoprotective drug. It is concluded that the methanolic leaf extract of $W$. volubilis showed high protective activity against aluminium sulphate $\left(\mathrm{Al}_{2}\left(\mathrm{SO}_{4}\right)_{3}\right)_{\text {. }}$. induced hepatotoxicity. Biochemical assays have potential value for assessing and monitoring the effectiveness and safety of pharmaceutical and medicinal therapy. The results suggested that $W$. volubilis could act as hepatic therapy without adverse effects at the metabolic activity and molecular levels in hepatic rats.

\section{ACKNOWLEDGEMENT}

It is proud to express my sincere thanks to the financial support extended from Indian Council of Medical Research (ICMR), New Delhi, in the form of a Senior Research Fellowship (SRF) to the first author (S. Usharani) is gratefully acknowledged.

\section{ABBREVIATION}

MEWV-methanol extract of Wattakaka volubilis

ATP-adenosine triphosphate

SDH-succinate dehydrogenase

$\alpha-\mathrm{KGDH}-$ alpha-ketoglutarate dehydrogenase

MDH-malate dehydrogenase

ICDH-isocitrate dehydrogenase

$\mathrm{Al}_{2}\left(\mathrm{SO}_{4}\right)_{3}$-aluminium sulphate

\section{AUTHORS CONTRIBUTIONS}

All the author have contributed equally

\section{CONFLICTS OF INTERESTS}

Declared none

\section{REFERENCES}

1. Levinthal GN, Tavill AS, Liver disease and diabetes mellitus. Clin Diabetes 1999;17:73-93.

2. Subramoniam A, Pushpangadan P. Development of phytomedicine for liver diseases. Indian J Pharmacol 1999; 31:166-75.

3. Muhtaseb MS, Talwar DEL, Duncan A, St J O'reilly D, Mckee RF, Anderson JH, et al. Free radical activity and lipid soluble antioxidant vitamin status in patients with long-term ileal pouchanal anastomosis. Colorectal Dis 2008;11:67-72.

4. Appiah I, Milovanovic S, Radojicic A, Nikolic Kokic A, Orescanin Dusic Z, Slavic M, et al. Hydrogen peroxide affects contractile activity and antioxidant enzymes in rat uterus. Br J Pharmacol 2009;158:1932-41.

5. Ishibashi H, Nakamura M, Komori A, Migita K, Shimoda S. Liver architecture cell function and disease. Semin Immunopathol 2009;31:399-409.

6. McNally P. GI/liver secrets: with student consult access; 2005;3:289.

7. Ostapomicz G, Fontana RJ, Schiodt FV. Results of a prospective study of acute liver failure at 17 tertiary care centres in the United States. Ann Intern Med 2002;137:947-54.

8. Fahaid Al-Hashem. Camel's milk protects against aluminum chloride-induced toxicity in the liver and kidney of white albino rats. Am J Biochem Biotechnol 2009;5:98-108.

9. Alfrey AC, LeGendr GR, Kaehny WD. The dialysis encephalopathy syndrome. Possible aluminum intoxication. Nat Eng J Med 1976;294:184-8.

10. Klein GL, Aluminum and hepatobiliary complications of total parenteral Nutrition. Gastroenterology 1993;10:1583-4.

11. Ward MK, Feest TG, Ellis HA, Parkinson IS, Kerr DN. Osteomalacic dialysis osteodystrophy: evidence for a water-borne aetiological agent, probably Aluminum. Lancet 1978;22:841-5.

12. Short AIK, Winney RJ, Robson JS. Reversible microcytic hypochromic anaemia in dialysis patients due to Aluminum intoxication. Proc Eur Dial Transplant Assoc 1980;17:226-33.

13. Gupta VB, Anitha G, Hegda ML, Zecca L, Garruto RM. Aluminum in Alzheimer's disease: are we still at a crossroad. Cell Mol Life Sci 2005;6:143-58.

14. Swartz R, Dombrouski J, Burnatowska Hledin M, Mayor G. Microcytic anemia in dialysis patients: a reversible marker of aluminium toxicity. Am J Kidney Dis 1987;9:217-23.

15. Chopra RN, Nayar SL, Chopra IC. Glossary of Indian Medicinal Plants $6^{\text {th }}$ reprint. New Delhi: NISCAIR; 2002. p. 258.

16. Anonymous. The Ayurvedic Formulary of India Part-1.1 $1^{\text {st }}$ ed. The government of India. Ministry of health and Family Planning; 1978. p. 257. 
17. Rastogi RB, Mehrotra BN. Compendium of Indian Medicinal Plants. Lucknow. New Delhi. CDRI and NISCAIR; 1985;4:763.

18. Divya TS, Latha PG, Usha K, Anuja GI, Suja SR, Shyamal S, Shine VJ, Sini S, et al. Anti-inflammatory analgesic and anti-lipid oxidative properties of Wattakaka volubilis (Linn. f.). Natl Prod Rad 2009;8:137-41.

19. Levekar GS. Data Base on Medicinal plants used in Ayurveda and Siddha. NewDelhi. Central council for research in Ayurveda and Siddha; 2007;8:272-8.

20. Madhavan V, Shukla A, Murali A, Usha M, Yoganarasimhan SN. Antipyretic activity studies of two botanical sources of the drug Murva. Asian J Trad Med 2010;5:51-60.

21. Burton K. A study of the conditions and mechanism of the diphenylamine reaction for the colourimetric estimation of deoxyribonucleic acid. Biochem J 1956;62:315-23.

22. Rawal VM, Patel VS, Rao GN, Desai RR. Chemical and biochemical studies on \ cataractous human lenses IIIquantitative study of proteins, RNA and DNA. Arog J Health Sci 1977;3:69-75.

23. Bonting SL. In: Membrane and Iron Transport. Vol. I. (Ed. Bitter EE), Wiley-Inter science, London; 1970. p. 257-363.

24. Hjerten S, Pan H. Purification and characterization of two forms of a low-affinity calcium ion ATPase from erythrocyte membranes. Biochem Biophys Acta 1983;728:281-8.

25. Ohinishi T, Suzuki T, Suzuki Y, Ozawa K. Effect of concanavalin A on the activity of membrane-bound and detergent-solubilized $\mathrm{Mg}^{2+}-\mathrm{ATPa} e$. Biochem Biophys Acta 1982;684:67-74.

26. Brandstrup N, Kirk JE, Bruni C. Determination of hexokinase and phosphorglucoisomerase activities of arotic and pulmonary artery tissue in individuals of various ages. J Gerentol 1957;12:166-71.

27. King J. The transferases-alanine and aspartate transaminases. In: Van D. Eds. Practical Clinical Enzymology, Nostrand Company Limitied. London; 1965. p. 191-208.

28. Slater EC, Borner WD. The effect of fluoride on the succinate oxidase system. Biochem J 1952;52:185-96.

29. Mehler AH, Kornberg AM, Grisolia S, Ochoa S. The enzymatic mechanisum of oxidation-reduction between malate or isocitrate and pyruvate. J Biol Chem 1948;17:961-77.

30. Reed LJ, Mukherjee BB. $\alpha$-ketoglutarate dehydrogenase complex from E. Coli. In: Methods is Enzymology. Lowenstein JM. Eds Academic Press: New York; 1969;13:55-61.

31. Bioj B, Moreto RD, Fairs RN. Membrane lipid fatty acid and regulation of membrane-bound enzymes. Biochem Biophys Acta 1973;311:67.

32. Stekhoven MS, Bonting BL. Transport adenosine triphosphatases: properties and functions. Physiol Rev 1981;61:1-6.

33. Benaim G, Cervino V, Hermoso T, Felibert P, Laurentin A. Intracellular calcium homeostasis in Leishmania mexicana. Identification and characterization of a plasma membrane calmodulin-dependent $\mathrm{Ca}(2+)$-ATPase. Biol Res 1993;26: 141-50.
34. Frank G, Wdzieczak-Bakala J, Henrotte JG. Modulating role of glucose on magnesium transport in rat erythrocytes. J Nutr Biochem 1999;10:433-7.

35. Sohal R, Dubey A. Mitochondria oxidative damage: hydrogen peroxide release and ageing. Free Red Biol Med 1994;16:621-6.

36. Bironaite $\mathrm{S}$, Ollinger $\mathrm{K}$. The hepatotoxicity of rhein involves impairment of mitochondrial functions. Chem Biol Interact 1997;103:35-50.

37. Tang X, Gao J, Wang Y. Effective protection of Terminalia catappa $\mathrm{L}$ leaves from damage induced by carbon tetrachloride in liver mitochondria. J Nutr Biochem 2006;17:177-82.

38. Gao H, Zhou YW. Anti-lipid peroxidation and protection of liver mitochondria against injuries by picroside II. World J Gastroenterol 2005;11:3671.

39. Shenoy KA, Somayaji SN, Bairy KL. Hepatoprotective effect of ginkobiloba against carbon tetrachloride induced hepatic injury in rats. Indian J Pharmacol 2001;33:260-6.

40. Mastern CJ, Holmes RS. In Hemoglobin isoenzymes and tissue differentiation North-Holland Publishing Company. Amsterdam, America; 1975. p. 103-20.

41. Kudryavtseva MV, Besborodkina NN, Kudryavtsev BN. Restoration of the glycogen-forming function of hepatocytes in rats with liver cirrhosis is facilitated by a high-carbohydrate diet. Br J Nutr 1999;81:473-80.

42. Baggetto LG. Deviant energetic metabolism of glycolytic cancer cells. Biochemie 1992;74:959-74

43. Ebrahim AS, Babakrishnan K, Sakthisekaran D. Perchloroethylene induced alterations in glucose metabolism and their prevention by 2-deoxy-dglucose and vitamin $\mathrm{E}$ in mice. J Appl Toxicol 1996;16:339-48.

44. Krithika Verma. Acta Poloniae Pharmaceutical and Drug Research; 2009. p. 579-83.

45. Mohanasundari M, Sabesan M, Sethupathy S. Renoprotective effect of grape seeds extract in ethylene glycol induced nephrotoxic mice. Indian J Exp Biol 2005;43:356-9.

46. Martinet W, Knaapen MW, De Meyer GR, Herman AG, Kockx MM. Oxidative DNA damage and repair in experimental atherosclerosis are reversed by dietary lipid lowering. Circ Res 2001;88:733-9.

47. Liu X, Pachori AS, Ward CA, Davis JP, Gnecchi M, Kong D, et al. Heme oxygenase-1 (HO-1) inhibits postmyocardial infarct remodeling and restores ventricular function. FASEB J 2006;20:207-16.

48. Soccal PM, Gasche Y, Miniati DN, Hoyt G, Berry GJ, Doyle RL, et al. Matrix metalloproteinase inhibition decreases ischemiareperfusion injury after lung transplantation. Am J Transplant 2004;4:41-50.

49. Ding YH, Li J, Rafols JA, Ding Y. Reduced brain edema and matrix metalloproteinase (MMP) expression by prereperfusion infusion into ischemic territory in rat. Neurosci Lett 2002;372:35-9. 